\title{
PENINGKATAN KEMAMPUAN MENULIS CERPEN MELALUI MODEL RANCANG BANGUN PADA PESERTA DIDIK KELAS IX A SMPN I TANJUNG
}

\author{
SUHENDRO \\ SMP Negeri 1 Tanjung, Brebes \\ Email : hendro0568@gmail.com
}

\begin{abstract}
ABSTRAK
Tujuan penelitian ini untuk mengetahui tentang peningkatan motivasi belajar peserta didik dalam penerapan model rancang bangun dan serta mengetahui peningkatkan hasil belajar mapel bahasa Indonesia terutama pada materi menulis cerpen. Dalam penelitian ini menggunakan dua teknik pengumpulan data yaitu dengan teknik tes unjuk kerja dan teknik observasi. Untuk menganalisis data, hasil tes unjuk kerja dan observasi dianalisis dengan deskripsi komperatif, yaitu membandingkan kondisi awal, siklus I, siklus II. Prosedur penelitian penelitian tindakan kelas (PTK) yang terdiri dari 2 (dua ) siklus.Pada siklus I diskusi dengan kerja mandiri yang terdiri dari 4-5peserta didik dipresentasikan dan ditanggapi oleh kelompok yang lain. Pada siklus II hasil diskusi kerja kelompok dipresentasikan di depan kelas dan ditanggapi oleh kelompok yang lain.Hasil penelitian dapat diketahui bahwa terjadi peningkatan kemampuan menulis cerpen dari kondisi awal rata-rata 69,30, setelah dilaksanakan tindakan siklus I ratarata 74,30 ,menjadi 88,4 pada akhir siklus II.Penerapan model rancang bangun, guru dalam proses pembelajaran lebih kreatif dan aplikatif.
\end{abstract}

Kata kunci: Kemampuan, Menulis Cerpen, Model Rancang Bangun

\section{ABSTRACT}

The purpose of this study was to find out about increasing students' learning motivation in the application of the design model and to find out the improvement in learning outcomes of Indonesian language subjects, especially in short story writing material. In this study, two data collection techniques were used, namely the performance test technique and the observation technique. To analyze the data, the results of performance tests and observations were analyzed by comparative description, namely comparing the initial conditions, cycle I, cycle II. The procedure of classroom action research (CAR) which consists of 2 (two) cycles. In the first cycle, discussions with independent work consisting of 4-5 students are presented and responded to by other groups. In cycle II, the results of group work discussions were presented in front of the class and other groups responded. The results showed that there was an increase in the ability to write short stories from an average initial condition of 69.30 , after the first cycle of actions was carried out an average of 74.30, to 88.4 at the end of cycle II. By applying the design model, the teacher in the learning process is more creative and applicable.

Keywords: Ability, Short Story Writing, Design Model

\section{PENDAHULUAN}

Kegiatan menulis cerpen merupakan sebuah proses kreatif. Proses kreatif yang dimaksud meliputi seluruh tahapan, mulai dari dorongan bawah sadar yang melahirkan karya sastra sampai pada perbaikan terakhir yang dilakukan pengarang (Wellek dan Werren 2014). Sebagai proses kreatif, keterampilan menulis membutuhkan kemampuan kompleks yang menuntut sejumlah pengetahuan dan keterampilan.Kegiatan menulis cerpen merupakan salah satu KD yang harus dipelajari oleh peserta didik di tingkat SMP. Di dalam silabus bahasa Indonesia SMP untuk KD menulis cerpen terdapat di kelas IX semester 1. Adapun KD yang dimaksud adalah sebagai berikut:(a) 8.1 menulis kembali dengan kalimat sendiri cerita pendek yang pernah dibaca;(b) 8.2 menulis cerita pendek bertolak dari peristiwa yang pernah dialami (BSNP 2006).

Kenyataan di lapangan terbukti bahwa keterampilan menulis merupakan sebuah aktivitas berbahasa yang tidak banyak disukai orang, termasuk peserta didik bahkan guru sekalipun. 
Ketikapeserta didik dan guru harus menghadapi materi tentang menulis, terutama menulis cerpen mempunyai kesan menghindar. Peserta didik menghadapi tugas menulis, mereka menganggapnya sebagai beban berat. Anggapan ini timbul karena kegiatan menulis membutuhkan banyak tenaga, waktu, serta perhatian yang sungguh-sungguh (Subyantoro 2009). Peserta didik kesulitan ketika diajakmenulis cerpen. Mereka kesulitan untuk menggali gagasan, memilih topik, dan menyajikannya dalam bentuk tulisan. Seorang guru juga merasakan bahwa materi ini membutuhkan waktu, tenaga, dan pikiran yang lebih jika dibandingkan dengan materi-materi lain. Apalagi guru yang sama sekali tidak menyukai sastra, materi ini akan dilewati begitu saja. Kalaupun mereka menjelaskan, penjelasan materi ini hanya bersifat teoretis.

Adapun masalah yang datangnya dari peserta didik adalah motivasi peserta didik dalam mengikuti pembelajaran menulis cerpen masih rendah. Rendahnya motivasi peserta didik dalam mengikuti pembelajaran menulis cerpen adalah (1) merasa tidak berbakat, (2) merasa tidak ada manfaatnya menulis cerpen, dan (3) merasa tidak mendapat bimbingan secara intensif dari guru dalam proses pembelajaran menulis cerpen (Nuryatin 2008).

Berdasarkan permasalahan tersebut, perlu adanya model pembelajaran menulis cerpen yang dapat meningkatkan motivasi dan kreativitas peserta didik untuk menulis cerpen dan sekaligus dapat meningkatkan kompetensi guru dalam membimbing peserta didiknya. Hasil beberapa penelitan berkaitan dengan model pembelajaran menulis cerpen. Amaliya (2006) melakukan penelitian dengan judul Model Pembelajaran Menulis Cerita Pendek Melalui Pemanfaatan Karikatur Media Massa dengan Teknik Gaya Personal. Hasil penelitiannya dapat disimpulkan bahwa ada perbedaan yang signifikan antara hasil pembelajaran sebelum dan sesudah menggunakan model pembelajaran menulis cerpen melalui pemanfaatan karikatur media massa dengan teknik gaya personal. Adapun Model pembelajaran yang dikembangkan peneliti adalah model rancang bangun pada pembelajaran menulis cerpen. Model ini merupakan mengadopsi dari berbagai model pembelajaran inovatif. Model pembelajaran ini berisi tentang merancang unsur-unsur intrinsik dan dibangun dalam bentuk karangan tahap demi tahap. Model ini diharapkan dapat mengatasi motivasi belajar peserta didik yang masihrendah. Hal ini tampak dari hasil uji kompetensi nialai rata-rata 69,3 dan dan ketuntasan belajar kalsikal 16,7\%. Ini berati pembelajaran menulis cerpen belum mencapai ketuntasan sebab daya serap kelas tersebut belum mencapai $85 \%$.

Sejalan dengan permasalahan di atas, maka perlu dipilh tindakan yang tepat untuk meningkatkan belajar peserta didik agar proses pembelajaran bahasa Indonesia pada materi menulis cerpen dapat secara optimal. Adapun tindakan yang dipilih peneliti dengan menerapkan model pembelajara Rancang Bangun. Model ini merupakan kreativitas penulis yang mengadopsi berbagai model pembelajaran.Seperti perihal tentang model,Aunurahman (2009)menguraikan beberapa contoh kelompok model pembelajaran yang dapat diterapkan guru secara sinergis melalui aktivitas pembelajaran yang dikelolanya menjadi 4 kelompok, yaitu: (1) kelompok model interaksi sosial (social interaction models) (2) kelompok model pengolahan informasi (information processing model), (3) kelompok model personal (the personal family model), (4) kelompok model sistem perilaku (the behavioral system family model). AdapunLangkah-langkah pembelajaran model Rancang Bangun sebagai berikut: (1)Tahap Rancang;Peserta didik diarahkan untuk mencermati contoh-contoh cerpensesuai dengan kehidupan peserta didik. Hal ini dilakukan untuk memberikan gambaran kepada peserta didik tentang bentuk-bentuk cerpen. Di samping itu, pada langkah ini guru memaparkan tentang cara menghidupkan tokoh, menyesuaikan latar, mengarahkan alur, dan menginternalisasikan sudut pandang. Guru membimbingpeserta didik untuk mengingat kembali peristiwa-peristiwa yang pernah dialami peserta didik.Peserta didik mengemukakan peristiwa-peristiwa yang pernah dialami. Kemudian guru mengajak peserta didik untuk memilih peristiwa-peristiwa yang pernah dialami serta mengesankan dalam kehidupan peserta didik.Guru mengajak peserta didik untuk menentukan konfliks-konfliks pada peristiwa yang paling mengesankan yang pernah dialami.Peserta didik secara berkelompok menenukan gagasan/ide sesuai dengan 
peristiwa yang pernah dialami. Peserta didik memilih gagasan/ide yang paling menarik dari peristiwa yang dialami kaitannya dengan kehidupan peserta didik. (2)Tahap Membangun; Peserta didik secara individu mengembangkan gagasan/ide yang ditemukan dengan memberikan konfliks-konfliks. Pemberian konfliks-konfliks ini dimaksudkan untuk menghidupkan tokoh, menyesuaikan latar, mengarahkan alur, dan menginternalisasi sudut pandang.Guru mengajakpeserta didikuntuk menuliskan pengalaman /peristiwa yang dialami yang sudah dirancang dari tema, penokohan, alur, dan sudut pandang. Kemudian peserta didik membangun ke dalam bentuk cerpen dari mulai penokohan, latar, alur, dan sudut pandang.

Tujuan dari penelitian ini adalah (1) Mendiskripsikan peningkatan kemampuan menulis cerpen pada peserta didik kelas IX SMP Negeri 1 Tanjung Kabupaten Brebes setelah diterapkannya model rancang bangun; (2) Mendeskripsikan penerapan model rancang bangun padapeserta didik kelas IX SMP Negeri 1 Tanjung Kabupaten Brebes.

\section{METODE PENELITIAN}

Prosedur penelitian tindakan kelas terhadap pembelajaran menulis cerpen ini telah peneliti lakukan sebanyak dua siklus. Setiap siklus ditempuh melalui empat langkah. Menurut Arikunto (2008) secara garis besar terdapat empat tahapan yang lazim dilalui dalam PTK, yaitu perencanaan,pelaksanaan, pengamatan, dan refleksi.

Subjek penelitian dalam PTK ini adalah 36peserta didik kelas IX A yang terdiri atas 18 peserta didik putra dan 18 peserta didik putri.Teknik pengumpulan data pada penelitian ini mengunakan tes formatif dan non tes berupa penilaian keaktifan maupun perilaku peserta didik pada saat pembelajaran berlangsung. Untuk alat pengumpulan data yang digunakan lembar kerja peserta didik, tes formatif, observasi, dan jurnal. Data yang diperoleh dalam penelitian ini terdiri dari data kuantitatif dan kualitatif. Data kuantitatif dari hasil tes formatif sedangkan data kualitatif hasil observasi dan jurnal. Teknik analisis data kuantitatif dilakukan secara deskriptif dengan menghitung jumlahrata-rata dan persentase ketercapaian.Adapun data kualitatif diperoleh dari hasil observasi, jurnal peserta didik, dan dokumentasi yang dianalisis dengan prosedur reduksi data, paparan data, dan simpulan.

\section{HASIL DAN PEMBAHASAN \\ HASIL}

Berdasarkan hasil penelitian yang penulis dapatkan setelah melakukan penelitian.

\section{Kondisi Awal}

Hasil belajar bahasa Indonesia pada aspek menulis cerpen dari nilai tes formatif tertinggi 85 nilai rata-rata 69,3 dan nilai terendah 50. Jumlah peserta didik yang hasil belajarnya memenuhi Kriteria Ketuntasan Belajar (KKM )sebanyak 24peserta didik. Hal ini dapat dilihat pada rentang nilai rata-rata kondisi awal tes formatif dapat dilihat pada tabel berikutnya.

Tabel 1. Hasil Belajar Kondisi Awal

\begin{tabular}{|l|l|l|l|}
\hline Rentang Nilai & Frekuensi & Rata- rata skor & $\begin{array}{l}\text { Rata-rata } \\
\text { Kemampuan }\end{array}$ \\
\hline $80-89$ & 6 & 80,8 & $16,7 \%$ \\
\hline $70-79$ & 18 & 71,1 & $50 \%$ \\
\hline $60-69$ & 10 & 63 & $27,8 \%$ \\
\hline $50-59$ & 2 & 50 & $5,6 \%$ \\
\hline Rata- rata & 36 & 69,3 & \\
\hline
\end{tabular}

Guru sudah menerapkan model pembelajaran, tetapi kurang inovatif, kreatif, dan tidak menyenangkansehingga peserta didik pasif. Hal ini menyebabkan prestasi belajar peserta didik rendah. Dengan demikian, dapat disimpulkan bahwa secara klasikal pembelajaran menulis cerpen belum mencapai ketuntasan. Hal ini karena peserta didik yang tuntas hanya mencapai $66,6 \%$. 


\section{Hasil Siklus I}

Melihat fenomena keadaan peserta didik kelas IX SMP Negeri 1 Tanjung,maka peneliti mengadakan Penelitian Tindakan Kelas ( PTK ) terhadap peserta didik kelas IX SMP Negeri 1 Tanjung yang berjumlah 36peserta didik,putra 18peserta didik, putri 16 siswi. Penelitian ini dilakukan sebagai upaya peningkatan hasil belajar bahasa Indonesia pada aspek menulis sebagai upaya gemar menulis cerpen melalui model rancang bangun dengan motode kerja mandiri dan kerja kelompok .

Tabel 2. Hasil Tes Kemampuan Peserta didikdalam Menulis Cerpen

\begin{tabular}{|l|l|l|l|}
\hline Rentang Nilai & Frekuensi & Rata- rata skor & $\begin{array}{l}\text { Rata-rata } \\
\text { Kemampuan }\end{array}$ \\
\hline $90-100$ & 1 & 90 & $2,77 \%$ \\
\hline $80-89$ & 10 & 82,5 & $27,77 \%$ \\
\hline $70-79$ & 21 & 71,90 & $58,33 \%$ \\
\hline $60-69$ & 4 & 62,5 & $11,11 \%$ \\
\hline Rata- rata & 36 & 74,30 & \\
\hline
\end{tabular}

Hasil kondisi awal sebelum tindakan dilakukan rata-rata 69,3, ternyata setelah diadakan tindakan siklus 1 nilai rata-rata 74,3. Jadi ada peningkatan sebesar $6,72 \%$.

\section{Hasil pengamatan (observer ) Siklus I}

Berdasarkan pengamatan proses tindakan yang kami lakukan dengan menggunakan model rancang bangun dengan metode kerja mandiri ternyata peserta didik dalam mengikuti proses pembelajaran lebih aktif jika dibandingkan dengan ceramah.Hasil pengamatan terhadap aktivitas guru dan peserta didik pada tindakan siklus I diperoleh gambaran sebagai berikut. Pada saat guru mengajukan pertanyaan apersepsi, hanya ada 2-3peserta didikyang dapat merespons pertanyaan guru.

Pada saat kegiatan diskusi, anggota kelompokaktif dan bekerja sama. Hal itu tampak dari peserta didikterlibat dalam kelompok diskusi.Peserta didik berani tampil memberikan jawaban secara lisan. Dalam mengerjakan tugas, peserta didik sudah dapat bekerja dengan tekun. Beberapa gangguan yang muncul masih dijumpai, di antaranyapeserta didik ada yang berbicara dengan teman sebangku. Hasil pengamatan pada siklus I, diperoleh hasil yang belum maksimal. Masih dijumpai banyak kekurangan yang akan diperbaiki pada siklus II.

\section{Hasil Jurnal Peserta Didik Siklus I}

Berdasarkan catatan jurnal peserta didik diperoleh gambaran tentang (1) kesan peserta didik terhadap guru, (2) kesan peserta didik terhadap cara guru mengajar di kelas, (3) kesan peserta didik terhadap materi, (4) kesan peserta didik terhadap penggunaan media, (5) kesan peserta didik selama mengikuti pembelajaran, (6) kendala yang dialami dalam pembelajaran, dan (7) pesan terhadap pembelajaran. Secara umum, tanggapan peserta didik terhadap guru, cara guru mengajar, materi, dan pelaksanaan pembelajaran menunjukkan suasana lebih hidup, bersemangat, termotivasi, dan menyenangkan. Hal itu teridentifiksi dari data kesan peserta didik terhadap sikap dan cara mengajar guru yang menyatakan bahwa (1) guru memberi kesempatan yang lebih leluasa kepada peserta didik untuk menemukan ide/gagasan, (2) guru sangat familiar, (3) guru banyak berinteraksi dengan peserta didik, (4) guru mudah diajak berbicara, (5) guru penuh perhatian dan selalu memberi bantuan kepada peserta didik yang mengalami kesulitan, (6) guru menyajikan pembelajaran dengan variatif, (7) guru memberikan bimbingan dengan penuh kesabaran, dan (8) guru menyajikan pembelajaran dengan membangun suasana yang menyenangkan. Hubungannya dengan materi ajar menulis cerpen, peserta didik menyatakan bahwa materi menulis cerpen yang dibahas sangat menyenangkan karena (1) contoh cuplikan cerpen yang disajikan penuh variatif, (2) menimbulkan efek peserta didik termotivasi untuk menulis cerpen, (3) dapat membuka wawasan, (3) dapat dilakukan oleh 
siapa saja karena berkenaan dengan pengalaman hidup peserta didik, (4) dapat mempermudah menemukan ide/gagasan, (5) mudah untuk mengembangkan ide/gagasan. Hal ini berarti materi yang disajikan guru mendapat perhatian peserta didik. Media yang digunakan memang dapat memberikan kemudahan bagi peserta didik. Namun, sebagian peserta didik menyarankan agar media perlu ditambah sehingga pembelajaran akan lebih menarik. Pernyataan ini memberikan masukan yang berarti bagi peneliti untuk menambah jenis media sebagai perbaikan pada siklus II.

\section{Hasil Siklus 2}

Siklus II dilaksanakan berdasarkan hasil refleksi dari siklus yang belum mencapai target keberhasilan penelitian.Tindakan pada siklus 2 direncanakan 4 jam pertemuan dengan 2 kali pertemuan. Setiap kali pertemuan dengan alokasi waktu 2 jam pelajaran selam 40 menit . Setiap pertemuan pembelajaran terdiri dari 3 bagian yaitu pendahuluan, kegiatan inti, dan kegiatan penutup. Alokasi untuk pendahuluan 10 menit, kegiatan inti 60 menit ,dan penutup 10 menit.

Tindakan yang dilaksanakan pada siklus II ini merupakan realisasi dari perencanaan tindakan yang telah disusun meliputi kegiatan-kegiatan selama pertemuan antara lain pendahuluan, kegiatan inti, dan penutup seperti apa yang tertulis pada perencanaan tindakan.

\section{Hasil pengamatan (observer) Siklus II}

Data siklus tindakan kedua, rata-rata keberhasilan meningkat menjadi 74,30. Dari rekapitulasi hasil pengamatan pada tindakan siklus kedua ini, tampak ada peningkatan dalam kemampuan peserta didik menulis cerpen. Hanya ada sedikit peserta didik yang masih Beberapa kendala yang dihadapi peserta didik adalah (1) kurang percaya diri dalam hal membacakan hasil karyanya, (2) mengomentari hasil pekerjaan teman, dan (3) terbatasnya waktu sehingga hasil pekerjaan kurang maksimal. Dari keseluruhan siklus tindakan, didapatkan hasil yang sangat memuaskan yang berkenaan dengan meningkatnya kompetensi peserta didik pada aspek menulis cerpen.

\section{Hasil Jurnal Peserta Didik Siklus II}

Adapun hasil catatan jurnal peserta didik diperoleh gambaran tentang (1) kesan peserta didik terhadap guru, (2) kesan peserta didik terhadap cara guru mengajar di kelas, (3) kesan peserta didik terhadap materi, (4) kesan peserta didik terhadap penggunaan media, (5) kesan peserta didik selama mengikuti pembelajaran, (6) kendala yang dialami dalam pembelajaran, dan (7) pesan terhadap pembelajaran. Tanggapan terhadap guru, cara guru mengajar dengan menerapkan model Rancang Bangun hasil menunjukkan peserta didik optimis, termotivasi dan menyenangkan. Hal dapat dilihat hasil tes formatif siklus II.

Tabel 3. Hasil Tes Kemampuan Peserta Didik dalam Menulis Cerpen

\begin{tabular}{|l|l|l|l|}
\hline Rentang Nilai & $\begin{array}{l}\text { Jumlah Peserta } \\
\text { didik }\end{array}$ & Rata- rata skor & Persentase \\
\hline $90-100$ & 2 & 90 & $5,55 \%$ \\
\hline $80-89$ & 15 & 82 & $41,66 \%$ \\
\hline $70-79$ & 19 & 73,42 & $52,77 \%$ \\
\hline $60-69$ & 0 & 0 & $0 \%$ \\
\hline Rata- rata & 40 & 84,4 & \\
\hline
\end{tabular}

Dari tabel 3 di atas dapat diketahui bahwa peserta didik kelas IX A SMP Negeri 1 Tanjung setelah mengikuti tindakan siklus II mengalami peningkatan kemampuan menulis cerpensecara signifikan jika dibandingkan dengan siklus yang pertama. Pada siklus kedua peserta didik yang tuntas belajar mencapai Kriteria ketuntasan Minimal sebanyak 36peserta didik.Hasil kondisi siklus I rata-rata 74,3, ternyata setelah diadakan tindakan siklus II nilai ratarata 84,4 . Jadi,ada peningkatan sebesar $11,9 \%$ dan mencapai ketuntasan $88,8 \%$ 


\section{LANGUAGE : Jurnal Inovasi Pendidikan Bahasa dan Sastra \\ Vol 1. No 2. November 2021, e-ISSN : 2807-1670 | p-ISSN : 2807-2316}

\section{Pembahasan}

Berdasarkan hasil analisis kemampuan menulis cerpen diperoleh nilai rata-rata84,4 meningkat sebesar $11,9 \%$, dimana sebelum pada siklus I rata-rata 74,30, dengan peningkatan $6,72 \%$. Sedangkan hasil kondisi awal nilai tes formatif rata-rata 69,3. Peningkatan kemampuan menulis cerpen menunjukkan bahwa model rancang bangun meningkat hasil belajar peserta didik pada materi cerpen.

Peningkatan hasil belajar peserta didik tergantung kompetensi guru dalam melaksanakan perannyadalam kegiatan proses pembelajaran. Hal ini, sesuai dengan Peraturan Pemeritah (PP) RI No. 19 tahun 2005 tentang Badan Standar Nasional Pendidikan (BSNP) ditegaskan bahwa pendidik (guru) harus memiliki kompetensi sebagai agen belajar.Seperti pendapatnya Mulyasa (2007) kompetensi guru merupakan perpaduan antara kemampuan personal, keilmuan, teknologi, sosial, dan spiritual yang secara kaffah membentuk standar kompetensi standar profesi guru, yang mencakup penguasaan materi, pemahaman terhadap peserta didik, pembelajaran yang mendidik, dan pengembangan pribadi dan profesionalisme. Sejalan dengan itu, guru dalamkegiatan belajar harus mampu mengorganisasikan dan mengarahkan peserta didik untuk mengerjakan menulis cerpen secara intensif. Guru mampu meningkatkan keterlibatan/partisipasi aktif peserta didik dalam pembelajaran. Guru juga sudah memanfaatkan sumber belajar/media pembelajaran dengan baik sehingga peserta didik termotivasi dan antusias untuk belajar dengan baik serta mampu meraih nilai di atas KKM yang ditetapkan.

Pembelajaran model rancang bangun merupakan model pembelajaran yang dikembangkan peneliti dari berbagai model pembelajaran inovatif dalam pembelajaran menuliscerpen.Sementara itu, Uno (2011) menyatakan bahwa model TidakTerarah (nondirective) adalah model yang menekankan pada kemitraan antara guru dan siswa yang tujuannya untuk memperkuat persepsi siswa terhadap dirinya dan mengevaluasi kemajuan dan perkembangan dirinya. Sani (2013) menambahkan bahwa model pembelajaran Tidak Terarah (nondirective) adalah model dengan tujuan pembelajarannya yaitu untuk membangun kapasitas belajarmandiri untuk pengembangan diri, memahami diri, otonomi, dan percaya diri, maka dapat disimpulkan bahwa model Tidak Terarah (nondirective) adalah model pembelajaran yang menuntut guruuntuk menjadi fasilitator yang berperan aktif dalam membangun hubungan danmembimbing siswa untuk memecahkan masalahnya sekaligus mengembangkan pengetahuannya secara mandiri. Adapu nsebagai perangkat rencana atau pola yang dapat dipergunakan untuk merancang bahan-bahan pembelajaran serta membimbing aktivitas pembelajaran di kelas atau di tempat-tempat lain yang melaksanakan aktivitas-aktivitas pembelajaran.

Langkah-langkah pelaksanaan pembelajaran model Rancang Bangun pada materi menulis cerpen di SMP N I Tanjung Brebes, Pada tahap merancang meliputi peserta didik mencermati contoh-contoh cerpen, mengidentifikasi tentang cara menghidupkan tokoh, menampilkan latar, mengarahkan alur, dan menginternalisasikan sudut pandang. Sedangkan tahap membangun menulis cerpen proses pembelajaran sebagai berikut.Peserta didik dibagi menjadi beberapa kelompok. Setiap kelompok terdiri atas 4-5 peserta didik dengan formasi duduk berhadap-hadapan. Peserta didik mengingat kembali peristiwa-peristiwa mengesankan yang pernah dialami. Secara berkelompok, peserta didik berdiskusi tentang peristiwa-peristiwa mengesankan yang pernah dialami. Peserta didik menuliskan pada LKS-nya masing-masing peristiwa-peristiwa mengesankan yang pernah dialami. Masing-masing anggota kelompok memilih peristiwa yang paling mengesankan yang pernah dialami kemudian menuliskan pada LKS yang telah disiapkan. Masing-masinganggotakelompok menentukan konfliks peristiwa yang paling mengesankan yang pernah dialami kemudian menuliskan pada LKS yang telah disiapkan. Masing-masing anggota kelompok menggunakan konfliks-konfliks tersebut menjadi 
kerangka cerpen. Peserta didik secara individu menyiapkan kerangka cerpen dari peristiwaperistiwa yang paling mengesankan yang pernah dialami. Secara individu, peserta didik mengembangkan kerangka cerpen yang telah disiapkan menjadi cerpen.

\section{KESIMPULAN}

Berdasarkan hasil penelitian tindakan kelas yang dilakukan di kelas IX A SMP Negeri 1 Tanjungsebagai berikut:

Penerapan model rancang bangun dengan motode kerja mandiri dan kerja kelompok dalam proses pembelajaran pada mata pelajaran bahasa Indonesia pada aspek menulis cerpen dapat meningkat. Di samping itu, penerapan model rancang bangunselain menigkatkan ketercapain pada bidang kebahasaan juga dapat meningkatkan aktifitas peserta didikserta mampu berkolaborasi dalam bekerja kelompok.

Langkah-langkah penerapan model rancang bangun dalam meningkatan kemampuan peserta didik dalam menulis cerpen.Tahap apersepsi: peserta didik dan guru bertanya jawab tentang menulis cerpen yang berkaitan dengan peristiwa yang dialami. Tahap rancang: peserta didik mencermati contoh-contoh cerpen serta peserta didik mengidentifikasi tentang cara menghidupkan tokoh, menampilkan latar, mengarahkan alur, dan menginternalisasikan sudut pandang. Tahap membangun: peserta didik dibagi menjadi beberapa kelompok dan setiap kelompok terdiri atas $4-5$ peserta didik dengan formasi duduk berhadap-hadapan, secara berkelompok, peserta didik berdiskusi tentang peristiwa-peristiwa mengesankan yang pernah dialami. Tahap Penulisan cerpen: peserta didik secara individu menyiapkan kerangka cerpen dari peristiwa-peristiwa yang paling mengesankan yang pernah dialami. Secara individu, peserta didik mengembangkan kerangka cerpen yang telah disiapkan menjadi cerpen yang baik.Tahap refleksi: guru dan peserta didik memberikan penilaian terhadap cerpen yang dibuat peserta didik.

\section{DAFTAR PUSTAKA}

Amaliya, Sely. (2006).Model Pembelajaran Menulis Cerita Pendek Melalui Pemanfaatan Karikatur Media Massa dengan Teknik Gaya Personal. Tesis. Bandung: Universitas Pendidikan Indonesia.

Arikunto, Suharsimi, dkk. (2008). Penelitian Tindakan Kelas. Jakarta: Bumi Aksara.

Aunurahman. (2009). Belajar dan Pembelajaran. Bandung: Alfabeta.

BSNP. (2006). Contoh/Model Silabus Mata Pelajaran Bahasa Indonesia SMP. Jakarta: Direktorat Pembinaan SMP Ditjen Mendikdasmen Depdiknas.

BSNP. (2008). Panduan Penilaian 5 (Lima) Kelompok Mata Pelajaran. Jakarta : Laksana Mandiri Putra.

Mulyasa, E. (2007). Standar Kompetensi dan Sertifikasi Guru. Bandung : PT Remaja Rosdakarya.

Nuryatin, Agus. (2008). Pembelajaran Menulis Karya Sastra Cerita Pendek: Memberi Bekal Live Skill Kepada Siswa. Makalah. Disampaikan pada Konferensi Internasional Kesusasteraan di Batu 12 - 14 Agustus 2008

Sani, Ridwan Abdullah.(2013).Inovasi Pembelajaran.Jakarta:BumiAksara.

Subyantoro. (2009). Pelangi Pembelajaran Bahasa: Tinjauan Semata Burung Psikolinguistik. Semarang: Universitas Negeri Semarang Press.

Uno, Hamzah. B,(2011).Model Pembelajaran Menciptakan Proses Belajar Mengajar yang Kreatif dan Efektif.Jakarta:BumiAksara.

Welek, Rene dan Warren Austin. (2014). Teori Kesusastraan. Jakarta: Gramedia 